\title{
Women's Transition to Entrepreneurs from Professional and Managerial Careers in Organizations
}

\author{
Nindria Untarini ${ }^{1 *}$; Sayyida²; Dwiarko Nugroho Seno ${ }^{3}$ \\ ${ }^{1,3}$ Department of Management, Faculty of Economics, Universitas Negeri Surabaya \\ Jln. Kampus Ketintang, Surabaya, Jawa Timur, 60231, Indonesia \\ ${ }^{2}$ Department of Management, Faculty of Economics and Business, Universitas Wiraraja \\ Jln. Raya Sumenep-Pamekasan KM. 05 Patean, Jawa Timur 69451, Indonesia \\ 1nindriauntarini@unesa.ac.id; ${ }^{2}$ sayyida-2017@feb.unair.ac.id; ${ }^{3}$ Dwirakonugrohoseno@unesa.ac.id
}

Received: $15^{\text {th }}$ May 2020/ Revised: $9^{\text {th }}$ July 2020/ Accepted: $3^{\text {rd }}$ August 2020

How to Cite: Untarini, N., Sayyida, \& Seno, D. N. (2021). Women's Transition to Entrepreneurs from Professional and Managerial Careers in Organizations. Binus Business Review, 12(1), 63-73. https://doi.org/10.21512/bbr.v12i1.6456

\begin{abstract}
Careers have different dimensions, they can be developed in an organization and in individual way. Organizations no longer have a role in creating careers, but individuals develop careers using the organization as a tool or medium. Changes in the external and internal environment in the organization are the basic conditions why individual career dares to change. The research aimed to explore senior female managers' phenomenon that left professional and managerial careers in organizations to be entrepreneurs. Structured and in-depth interviews were conducted with 25 female entrepreneurs who had left senior manager positions at the companies. Qualitative research approaches were carried out to explore what motivated female entrepreneurs to make a career transition and how the career transition process was done. Then, the Critical Incident Technique was used to analyze the data to get responses regarding female entrepreneurs' perceptions of career transitions. From the results, there are four main categories: personal, organizational life, value and integrity, and capital. Then, there are also nine subcategories: independence and individualism, strong encouragement and family support, professional and personal life balance, organizational life, values, integrity, partner ties, mentor ties, and human capital. The personal category causes more women to make a career transition, followed by capital, value and integrity, and organizational life categories.
\end{abstract}

Keywords: women's transition, women entrepreneurs, professional career, managerial career

\section{INTRODUCTION}

Women in management have become an important topic as they hold only a few senior managerial positions in the company (Hancock \& Hums, 2016). A survey conducted by McKinsey and Femina survey institutes indicated that in 2016, from 500 working women who held positions of junior manager, executive, and CEO throughout Indonesia revealed that $47 \%$ held positions at the entry-level. It was only $20 \%$ for middle-level management. Then, the number was smaller at the director level $(6 \%)$ and for CEO position (5\%). However, these women left the company to set up their business. Women withdrew from work and started a business when having difficulty in developing a career in senior management positions (Sharma \& Kaur, 2019).
Careers are seen as volatile conditions. The argument is that in the era of globalization and other competitive pressures, organizations have experienced streamlining and separation of functions to reduce the structure that supports traditional careers. Careers are no longer seen as advancing up through the organizational hierarchy. According to theorists and commentators, careers are organized as adventures without limits and portfolios (Baruch, Szücs, \& Gunz, 2015). Boundaryless careers have the characteristics of flexible work relationships, transferable skills in several companies, learning action at work, personal identification related to the meaning of work, network development and colleague relations, and individual responsibility for career management (Baruch \& Reis, 2016).

Women apply their careers differently from men 
(Yi, Ribbens, Fu, \& Cheng, 2015). In particular, they are in the benefits of transitioning the structure of the organization and the beginning of boundaryless careers (Baruch \& Reis, 2016). High involvement of women in employment could be seen from the ILO report in 2010. There was an increase in the participation of female workers in 1980 and 2008 from 50,2\% to $51,7 \%$ (ILO, 2011). Women instinctively have a caring role in the family, but the involvement in work and the demands of work increasingly make them vulnerable to conflict. The division of less balanced work duties makes them experience difficulties in their lives, especially balancing family and work since both of these roles require them to take part. In their work, they are required to make many decisions. With the complexity of the dual role, they can run both professions as housewives and office employees (Ghanbari, Sarooghani, Darabi, Bahri, \& Abolfathi, 2017).

When work roles and family roles are incompatible, work-family conflicts can occur (Sheikh, Ashiq, Mehar, Hasan, \& Khalid, 2018). Workfamily conflict arises from the work environment of family relationships. When an individual prefers to work, she or he will potentially experience problems of meeting the obligations and needs in the family (Cooklin et al., 2016). Women prefer to look for a new career that is more flexible when they feel that their life patterns and rhythms are not appropriate (Baruch \& Reis, 2016). Simultaneously, the emerging forms of careers do not provide opportunities for women to occupy a higher management level than men. This lack of opportunity makes women make career changes to entrepreneurship. There is an increase in women's interest in opening their businesses or entrepreneurship (Goltz, Buche, \& Pathak, 2015). The increasing population of female entrepreneurs with experience of working in companies or management is called career entrepreneurs, corporate incubators, corporate climber, modern entrepreneurs, and secondgeneration entrepreneurs (Costa, Caetano, \& Santos, 2016).

The motivation of career women to become entrepreneurs can be predicted based on salary inequality, career frustration due to glass ceilings, and the promise of flexibility from entrepreneurship (Pérez-Pérez \& Avilés-Hernández, 2016). However, most of them make voluntary career transitions, and some of them are forced (Justo, DeTienne, \& Sieger, 2015). The cause of women's career transition occurs by force due to organizational context factors, that is not by the company, downsizing, and several other company policies (Ramanath, 2016). Career transition is caused by two things: voluntarily and involuntarily (Hennekam \& Bennett, 2016). The term voluntarily means that career transitions are carried out purely on a personal/individual basis. Meanwhile, involuntarily is based on an element of compulsion formed by the individual or environmental constraints.

Academic research is limited to the study of the institutional or individual motivation of women
(Henley, 2015). In this sense, few studies examine the choice of an entrepreneurial career due to a career transition or career transfer. Career change is equal to career transition and is interpreted as a work-life transition process experienced by someone due to changes in actual job, work-life, or the subjective perception (Lyons, Schweitzer, \& Ng, 2015). Some researchers still link career changes or career transitions to the organizational sphere, such as career promotion (Du Plessis, 2015) and career transfer (Miscenko \& Day, 2016). Women make the intended career change or career transition in the research because of the urge to move out of their previous career in an organization when they succeed in recognizing the benefits of the organizational structure transition and learn to seek a new job that is more flexible (boundaryless careers).

In the current career context, the career transition to entrepreneurship is due to realizing more independent choices and eliminating excessive reliance on rules in the organizations. Career transition can be in the form of job transfers or moving work areas, promotion, demotion, or accelerated retirement. The term of career transition is equal to a career change (Hoyer \& Steyaert, 2015). It is defined as the main changes that occur to the needs of work roles and work contexts and as part of the process of changing work or changing one's orientation from his or her new job. Some research focuses more on career transitions that are limited to the concept of company scope or job transfer (Wang \& Wanberg, 2017). It also has psychological changes experienced by a person due to the career shift. According to Page-Jones and Abbey (2015), career change is caused by someone wanting to generalize or the emergence of new opportunities.

Although previous researchers on careers have discussed concepts such as independence, autonomy, and freedom, called the career portfolio (Wright, Marsh, \& Mc Ardle, 2019), they do not mention the concept of entrepreneurship. It becomes an interesting question. At the same time, there is limited literature on entrepreneurship that refers to the current career literature and hardly identifies its relevance. It still overlaps between career form and discourse. Some writers mention that a person's tendency to make the transition from organizational work and build a business is a change in a more mature model of independence (Falco \& Haywood, 2016). Other studies are interested in distinguishing retaining entrepreneurship caused by changes in organizational conditions or as a calling itself (Fuller, Liu, Bajaba, Marler, \& Pratt, 2018; Foss, Klein, \& Bjørnskov, 2019).

Recent studies have focused on female entrepreneurs (small business owners). The number of entrepreneurs has increased (Goktan \& Gupta, 2015; Hasan \& Almubarak, 2016). In Indonesia, the results of research conducted by the Global Entrepreneurship Monitor, starting from 2013-2016, female entrepreneurs accounted for $40 \%$ of the population. Women with business ownership reached $14 \%$. It meant that 14 out of 100 people opened new businesses until their businesses were 3,5 years old 
in 2016. The achieved value of $14 \%$ made Indonesia rank 20 out of 65 countries. The number of women was more than men in opening a business. The ratio was 1,24 or 5 women compared to 4 men. Women's participation in entrepreneurship increased from $48,87 \%$ to $55,04 \%$ (Rey-Martí, Tur Porcar, \& MasTur, 2015; Campos, Goldstein, McGorman, Boudet, \& Pimhidzai, 2015). These findings confirm the significant contribution made by women entrepreneurs in the economy in Indonesia. It has become interesting to study women in entrepreneurship that can function as challengers of old thoughts about entrepreneurship, motivation for entrepreneurship, and a measure of success in entrepreneurship.

In connection with the career transition or career change that is the topic of the research, it emphasizes how women move careers from the previous employee to self-employment or become entrepreneurs. Careers have different dimensions. Organizations no longer have a role in creating careers, but individuals develop careers using the organization as a tool or medium. Changes in the external and internal environment and human resources in the organization are the basic conditions why careers are more dominated by individuals' ability as organizational resources. Career contracts with the start of the next millennium will be different from current career contracts. Employees are no longer bound by traditional work contracts where they enter the company, work hard, perform well, be loyal, commit, receive higher compensation, and so on. New career contracts are based more on continuous learning and identity change called the way of the heart (Hall, Yip, \& Doiron, 2018).

The research seeks to bring together several concerns in understanding career transitions from organizational work of relatively unlimited career forms (boundaryless), especially in women. Given the importance of entrepreneurial centrality in recent career literature, it is essential to study the career transition to entrepreneurship in a more flexible career transition context. However, previous studies still have limitations to understanding entrepreneurship as a potential response to organizational change and career rhetoric (Feldner \& Fyke, 2016) and how individuals experience and change careers (Agarwal \& Lenka, 2015).

The research is based on the transition of women from employee to self-employment or becoming entrepreneurs. This topic is interesting for several reasons. First, women in middle and senior positions tend to leave a career for entrepreneurship where conditions occur in an organization that is still developing (Hoyt \& Murphy, 2016). Few empirical studies are related to career choices to become entrepreneurs due to women's career transition or career transfer from a previous career. Second, qualitative research generally emphasizes that career transitions for women are forced or involuntarily, and career transitions do not just mean entrepreneurs. Third, career transition processes are generally carried out by women. It concludes that there are differences in career transition patterns between women and men (Ibarra \& Petriglieri, 2016). Thus, an analysis of the transition to women that work in organizations to become entrepreneurs will provide insight into the extent to which careers are an alternative to the new and flexible workforce. Based on the data generated in the research, it considers two main objectives. First, it is critical incidents experienced by female entrepreneurs in deciding to choose entrepreneurs rather than merely changing organizations. Second, it is how far women understand how they cope with difficult situations in the career transition process.

The results of the research are expected to make a role model of career transition to the employee to self-employment or to become female entrepreneurs. It includes various aspects that influence behavioral change formation based on the reasons for career transition in the current career discourse (Hasan \& Almubarak, 2016). It is also expected to have managerial implications in understanding employees' career transition and how the program from human resource management can help employees to adjust to the career transition.

\section{METHODS}

The purpose of the research is to analyze the critical incidents experienced by female entrepreneurs in deciding to be entrepreneurs rather than merely changing their organizations and understand how they cope with difficult situations in the process of leaving their careers. The research adopts an interpretive approach. It seeks to explain the phenomenon in question from the subject's perspective without imposing an external perspective. According to Taylor, Bogdan, and DeVault (2015), to grasp the intent of someone related to their matters and environment, it is necessary to understand the phenomenon from the participant's perspective.

The research uses Critical Incident Techniques to identify activities, events, processes, and others that are experienced by female entrepreneurs in difficult situations to leave their careers and choose entrepreneurship. In this case, a critical incident is a serious situation experienced by the interviewed female entrepreneurs, causing them to make a career transition. This technique allows the interviewee to remember their experiences in their words/sentences.

The participants have left senior management positions in companies and set up their businesses in Indonesia. There are several main criteria. First, an entrepreneur is defined as an individual that starts a business, has at least $50 \%$ business ownership, and is actively involved in management. Second, they have management experience in the company for at least five years. Third, career transitions are purely based on their willingness (voluntarily) and become entrepreneurs. Fourth, the business is in the initial stages of business establishment, such as in the five months to three years, and has been stable or has passed the critical period at the start-up stage. These 
female entrepreneurs are identified by a network of the Womenpreneur Community (WPC) in Surabaya.

The sampling method is a hybrid between purposive sampling and snowballs. The selection of purposive sampling is based on the previously explained sample criteria. Meanwhile, the reason for choosing snowballs is one respondent will recommend the next respondent and so on, according to the characteristics. From the method, 25 female entrepreneurs participate in the research.

Data collection begins by asking participants to complete open questionnaires through online and offline mail with two questions. Participants describe difficult experiences when they decide to leave their careers and how they feel at the time. Then, they explain the reasons for choosing entrepreneurship as the next career choice and the reasons for the decision. Because they do not enter their names on the questionnaire, they are identified by a letter followed by the researchers. The questionnaire is completed in 35 minutes. For the research, the entered data units are constructed based on a priori (according to the theoretical and conceptual framework) or apostrophe (inductively prepared from the data). The objectives and research problems use a posteriori categorization (open categorization) generated from research findings.

After reading and organizing data sequentially and repeatedly, the researchers modify, divide, and categorize it until a trusted conceptual pattern emerges. Each category in terms of the cause of career transition is named. Next, the researchers develop incident classifications and compare these classifications. Different schemes and opinion are resolved through discussion. Through this process, a final classification scheme is gradually arranged. All incidents are sorted into various scheme categories.

Then, consulting with two experts on management disciplines is conducted. They have a background in management and work independently. They are asked to rate and sort categories according to a particular scheme. Then, they compare their results by calculating the reliability score. The results of the classification are tested by comparing the similarities between categories. A reliability score of more than $80 \%$ is considered feasible (Chuang \& Tai, 2016). If there is a disagreement, it will be discussed again. Then, a frequency table of the causes of career transitions is made so that the researchers get mutually exclusive and exhaustive categories. Last, the researchers discuss the remainder of the different categorizations for agreement and calculate the frequency of incidents affecting career transition.

\section{RESULTS AND DISCUSSIONS}

During the data collection process, 25 participants are interviewed, and about 66 incidents are collected. Overall, each informant's answer varies from one incident to six incidents. There is average of four incidents that are problems during their career transition. According to Mensah-Kufuor, Mensah, and
Amenumey (2015), there are 50 incidents that allow researchers to proceed to the category creation stage. It is a subjective process that looks for natural groups in the incidents. After repeated and thorough reading and sorting data, it makes sense for a particular group to be formed. Each category and subcategory give a detailed explanation so it can be understood. Therefore, out of 66 incidents, 4 categories and nine subcategories are formed following the categorization classification process to illustrate the essence of the incidents.

Reliability analysis is conducted to improve the reliability of the categories formed by the first researcher. As the second researcher is not involved in the classification of initial incidents, the researcher classifies all incidents that are formed following a certain set of instructions. It needs to do data assessment, as suggested by Perreault and Leigh (1989). After reading the descriptions of each category, the second researcher encodes 66 incidents. Based on the reliability test, the results obtain a value of $85 \%$ in the classification system. Classification system reliability is considered satisfactory if interjudge reliability is equal to or greater than $80 \%$ (Bott \& Tourish, 2016).

The classification schemes are created to respond to the original purpose of the research based on data collected. Four categories are obtained: personal, organizational life, integrity and value, and capital.

The first category contains all incidents related to personal perception's capacity for a career transition to psychological limits (Van der Horst, Klehe, \& Van der Heijden, 2017). Thus, the psychological dimension of a boundaryless career is more relevant to subjective career success so that it emphasizes more autonomy, affiliation, variety, and novelty (Gerli, Bonesso, \& Pizzi, 2015).

All participants show their choices to choose entrepreneurship. It is by reflecting on the opinions about self-employment (Henley, 2017). The core of their career stories in the personal category leads to independence and individualism, strong encouragement and family support, and personal and professional life balance.

This subcategory (independence and individualism) tells how the participants want to be their boss and have control and flexibility in their career orientation. Most participants reveal as follows:

"There are times when we have to choose to start freeing ourselves whether it is for more time for family and considerations to be more financially independent."

"I see there is a freedom when we are an entrepreneur, so we are independent in terms of managing time and fund, and making policies."

Then, five participants $(20 \%)$ do not have a business background but leave their organization in 
a positive spirit to work alone. They plan and direct their careers by not relying on the company they work for. They pursue a linear career, enjoy it, and reach a high position in the job hierarchically. However, they feel it is time to move on to other challenges as they mention:

\begin{abstract}
"Being an entrepreneur has become my goal since graduating from college. I feel that my decision to leave the company and open a new business is the right decision, and I never regret it. It does not mean because my business is now successful. If my new business fails at an early stage, I never regret leaving and becoming an anti-career. Precisely, if a failure occurs, it demands me to study more and keep learning."
\end{abstract}

After choosing a career as a professional in an organization, entrepreneurship is considered a viable career choice. The question is not about if they will become entrepreneurs, but when they will start a business. They are waiting for "independent triggers" (Paustian-Underdahl, Halbesleben, Carlson, \& Kacmar, 2016). It is consistent with other research regarding the background of people that work alone (Johannessen, Engedal, Haugen, Dourado, \& Thorsen, 2018). Although initially, they do not imagine themselves as part of their career development, they make what they describe as well-thought-out and wellplanned decisions towards a career without limits.

The other subcategory is strong encouragement and family support. About seven participants $(28 \%)$ in this group have an entrepreneurial background. Their move to entrepreneurship is encouraged and supported by their families. Hence, the self-employee for these participants is not fantastic, and it is a common thing. They say:

"The family becomes a booster to be more independent. Incidentally, the family fully supports my decision. So, it needs the support of your closest family in doing all this."

"The desire to continue to be with family and the supports of parents and husband further strengthen me to leave my career."

Next, another subcategory is a personal and professional life balance. Gender emerges as the main theme in the stories of some participants. However, interestingly, during the interview, it becomes clear that the mothers' status as one of the factors that lead to their career transition. It is discussed explicitly by most participants by explaining how family responsibilities have given them socially valid reasons to leave their careers. Meanwhile, the desire for more autonomy and greater control in the workplace is little discussed as a reason to leave a professional career, even though one participant raises this point. However, most of their desires just want to do the best in the family. Some participants say that their decision to leave the organization attempts to solve more work problems and their identity as a working woman.

The stakes are high for participants who struggle with contradictory pressures for being a good mother and a good employee. The essence of their conflict is the happiness and well-being of children, the success of the organization, and their self-esteem as mothers and professional workers. The tensions between the household and work are structurally realized. In terms of accommodating the physical and ideological needs of the family in terms of organizational attitudes towards responsibilities as professional workers, they mention:

"Personal status as a single parent (even though it was eight years ago), more and more children need greater attention and costs, which in the future may not be covered if they remain employees in the old organization."

"The limited time for my beloved child, which is confiscated by my work routine at the office, is the biggest motivation to leave the company."

After making a career transition to entrepreneurship, some participants describe the emergence of issues related to status clarity. In particular, they feel a clear loss of status in the eyes of those who have seen them as career women. They say:

"At the beginning (approximately three months earlier), I felt that time was running very slowly and experienced an identity crisis formerly known by my name, now known as a mother by the name of a husband). Various routines, along with the status and respect I received when I was an employee, suddenly disappeared."

"As a career woman, this was a difficult choice for me, who was accustomed to working, earning her income, and meeting people. Now, I have to be a full-time housewife to take care of my husband and children."

In entrepreneurship, they hope to achieve a balance that is not given to them when working in organizations. Despite their awareness in developing a new career, they feel they have jeopardized their professional legitimacy.

The second category (organizational life) tells the story of six participants that are in a state of anger, bitterness, and even despair about the organizations. The drive for entrepreneurship does not always relate to personal choices, but it can be the responses to those circumstances. Here, the participants experience dissatisfaction with organizational life. Dissatisfaction is not similar to what the managers have experienced and expressed similar concerns in other studies (Sperandio \& Devdas, 2015; Devi \& Rani, 2016). However, it is more related to how they feel frustrated that there is a little opportunity to develop professionally in their 
organizations. It is in terms of promotion, learning, and professional growth. For such people's condition, the work challenges are not achieved, and they feel stagnation, stiffness, boredom, and time-wasting and hinder their creativity. For example:

"Being the leader or top leader in the company, of course, there were still many things that blocked and hampered our creativity so I needed more space to explore other talents and skills."

"To be honest, I like to trade. Incidentally, I do not feel comfortable working at the company, so my determination is in the business world."

From the previous example, it is known that all incidents that occur in women during career transition in organizational life are more directed to the actual transition between work, company, type of work, and country (Van der Horst et al., 2017). In other words, physical mobility orientation is more directed towards money, status, promotion of interest, and lack of job security.

The third category is value and integrity. The first subcategory is value. Another meaning of the value here is an attempt to balance a seemingly radical career transition with long-standing personal values and orientations. There is a difference between a person's professional value system, the organizational system, and the powerlessness that a person feels to influence change (Ogliastri \& Zúñiga, 2016). The problem of power, legitimacy, and the right to define organizational reality is not only the value of the organization but also the people who are valued (Sperandio \& Devdas, 2015). Moreover, they want to show the actualization of their ability in entrepreneurship compared to only receiving a salary if they become an employee (Devine, 2019), especially in the professional and managerial fields, and have higher satisfaction from entrepreneurial careers (Braches \& Elliott, 2017). As a result, some senior female managers will opt out of the organization and start hiring themselves if they feel that they receive higher benefits of entrepreneurial career choices. In their story, the organization is no longer a place to improve the quality of life, and they believe that it is not possible to change the organization to respect them better. For example:

"I felt that the income I earned by establishing a Japanese restaurant was higher than my salary as a civil servant. Initially, I was hesitant to start a business. In the past, I also did not know how to start and had no experience. I did not believe that entrepreneurship was my talent. I felt more excited by being a businessman even though civil servants also offered comfort. However, the business income that I got was far higher than when I was a civil servant. Finally, I decided to stop being a civil servant after my turnover was high."
The second subcategory (integrity) tells the story of eight participants (32\%). It explains how their decision to leave their professional career as a manager is directly related to the fundamental contradictions between the value system, organizational principles, and the introduction of ideas that are not the values and principles that they expect. In this case, external and internal changes result in new ways to understand the organizational realities that do not follow their principles and values. The participants think that it is impossible to reconcile the value system and principles of the organization to their perceptions between religious individuals and professional individuals. As an example:

\begin{abstract}
"I decided to leave my career at the bank starting when I worked in Madura as a branch head. In Madura, the people were religious, and I met with a variety of recitation communities. One of the study forums discussed what usury was and how the characteristics of usury were. It also mentioned the sin of usury, such as adultery with one's mother. I liked finding a bright spot. It was like a person that walked into a dim cave, and then there was a light that illuminated the cave. Gaining such knowledge, I became more active in participating in the studies and explored usury and all kinds of the path to usury. Frankly, I was devastated. What I had done so far (working at the bank) was included in the category of usury. After considering it for a few weeks, by saying basmalah, I submitted a letter of resignation."
\end{abstract}

Different value systems and principles between individuals and companies encourage women to develop careers outside the organization. When gaps arise from career orientation, they will leave their jobs because they may not reconcile the system of values and organizational principles that are not what they expect.

The last category is the capital. This category explains how women's motivation leaves their professional careers to start a business based on the persuasion of social capital, financial capital, and human capital. There are several subcategories. First, there is social capital: partner ties. About 15 participants $(60 \%)$ report that they start their business without any connection to partners. Around 10 participants (40\%) state that they involve their partners, friends, and family as business partners. Previous research mentions that new business is often started by two, three, four, or five business groups (Muñoz-Bullon, Sanchez-Bueno, $\&$ Vos-Saz, 2015). Adopting a classification developed by Svejenova and Alvarez (2017) as an impetus for starting a business focuses on the origin of partners as working relationships and types of roles. About 10 participants $(40 \%)$ speak openly about partner choices as an encouragement to start a business. The example can be seen as follows. 
"After a few months I was unemployed, I met with customers at the bank where I used to work. He invited me to sell car spare parts. For a long time in struggling to be a spare parts sales, God finally brought me together with someone to open a shop until now. Just believe in God. The important thing is what we endeavor. The problem is the result we leave it to God and most importantly stay away from usury."

Broad social networks are capital for women to establish working relationships in starting a business. Business partners provide opportunities for them to learn and gain broader market segmentation. However, some women do not start their businesses by including business partners.

Second, there is social capital regarding mentor ties. Five participants $(20 \%)$ mention that their mentors come through working relationships in the interview process. Another participant explains how she starts her business by joining a business community from which she gains business knowledge and practices and business partners.

"Luckily, I meet a lot with various business communities in the city of Yogya and Jakarta so that the spirit of entrepreneurship is maintained. Joining the entrepreneurial community is the beginning of the path to success. Some of the successful efforts that we make with colleagues in the positive community are classy tent and tent rental business. The refill ink refill business is also successful as the construction service business. In those, we are collaborating with several old colleagues and friends in the community."

However, there are also other participants explaining parents as mentors as they are involved in business activities. A participant who is a former manager of a private bank that currently does the repair shop business with the concept of a mini-market talking about the role and support of her father:

"Support from parents strengthens me to leave my career. Incidentally, my parents are also entrepreneurs in the same business field. So, I can learn directly from my father related to the business that I make with my husband."

It is consistent with previous research. The women describe the role of mentors from work and family as entrepreneurial career development (Cesaroni \& Paoloni, 2016). Likewise, Jabeen, Katsioloudes, and Das (2015) argued that the family aspect played a role in the success of a business run by female entrepreneur, but it was not the main driving factor.

The last subcategory is human capital. All participants have previous work experience in the industry before they start their new business.A participant, whose initial job is Branch Coordinator and the representative of the leadership at the Jakarta Consulting Group for the Surabaya branch office, talks about how she carries out her career and gains new competencies, especially in the field of management consulting. Her previous work experience gives her the expertise to "know-how" to start and run a management consulting business from a previous company:

\section{"My experience and background now put me in a position where I feel confident about running my business now. The company has facilitated me to study fully to become an independent person beyond what I imagine."}

However, not all the described training and development experiences are useful for starting a new business. Another participant who quits her job regrets some of her company's investments:

"I practically grew up in a garment company. It was the first time I quitted my job. Even though I now open an apparel retail business, I learn to manage a business, design strategies, organize employees, and manage my way. I develop different strategies and ways to provide services to our customers."

Previous work experience in companies provides opportunities for women to experiment with entrepreneurial business models, knowledge, and skills to start their businesses in the future. For some of these individuals, work within the organization is a means of achieving objectives that lead to business ownership. However, some types of human capital are not always reported as input for establishing a new business. A summary of the results of the category classification is explained in Table 1.

Table 1 shows the results of the categorization process in the causes of career transitions. It results in four categories and nine subcategories. It also shows the frequency and percentage of incidents in each category. The subcategories in the first category have the highest rate of $54,6 \%$ of reported incidents. So, the most reported incidents are about the personal category. For example, the desire to be more independent, support from the family, and the desire to get a balanced life between professional and personal life are more dominant for women to make a career transition from professional to entrepreneur. It is based on the responsibility of women as mothers that give social reasons to leave their careers. Personally, a strong drive to provide the best for the family and family support make them voluntarily leave their professional careers. The second highest subcategory is human capital and organizational life at $9,1 \%$ of the total incidents. The least reported incidents are related to social capital with $7,6 \%$.

In a career age without limits (boundaryless career), the concept of an embedded career capital 
Table 1 Category Classification

\begin{tabular}{cccc}
\hline CATEGORY & SUB-CATEGORY & FREQUENCY & PERCENTAGE (\%) \\
\hline $\begin{array}{c}\text { Category 1: } \\
\text { Personal }\end{array}$ & Independent and individualism & 19 & 28,8 \\
& Strong encouragement and family support & 7 & 10,6 \\
& Professional life balance and personal & 10 & 15,2 \\
Category 2: & Total & 36 & 54,6 \\
Organizational life & Organizational life & 6 & 9,1 \\
Category 3: & Total & 6 & 9,1 \\
Value and integrity & Value & 4 & 6 \\
& Integrity & 4 & 6 \\
Category 4: & Total & 8 & 12 \\
Capital & Social capital: partnership ties & 5 & 7,6 \\
& Social capital: mentorship ties & 5,6 & 7,1 \\
& Human capital & 5 & 24,3 \\
& Total & 6 & 100 \\
\hline
\end{tabular}

is expressed as human capital and social capital competencies that can be transferred from experience to new ventures. The investment of senior female managers in human capital and social capital helps them to start new businesses. This statement is in accordance with Gerli et al. (2015). Individual emotional competence affects the tendency to carry out career mobility and career progression related to social competence. In interviews, several participants contribute to human capital, such as previous work experience and social capital in the form of partners and mentors in stimulating them to make a career transition. Some participants also mention their experiences when starting a business, such as a busier schedule between business, works, and family. It makes the quality of life seem to decline. Other participants also say that the business is tiring, and the delegation processes are slow and challenging at the beginning. Although, in reality, there are still challenges and obstacles for women in entrepreneurship, the research can answer the reasons for career transitions and their process.

\section{CONCLUSIONS}

The purpose of the research is to find out more about women's motivation in making a career transition to starting their business. The research discusses questions related to women's motivation in a career transition to entrepreneurship and how they make the transition process. Data analysis is performed to answer the research objectives. Based on data analysis results, the research shows four categories: personal, organizational life, values and integrity, and capital. There are also nine subcategories: independence and individualism, strong encouragement and family support, professional and personal life balance, organizational life, values, integrity, partner ties, mentor ties, and human capital.

In the first category (personal), the decision to leave a professional career and enter entrepreneurship is very relevant. Women always have a positive spirit to grow in a different direction from the organizational career. Strong entrepreneurship and family support stimulate them to make a career transition. Aside from independence, the need for more flexibility and autonomy also contributes to career transition. However, the impact is only slightly discussed as a reason for leaving a professional career. Women's nature as mothers that must educate and care for children and the demands of a balance between mothers and their responsibilities as professional workers cause family conflicts. This condition also causes them to change careers.

The second category is triggered by organizational life. These women's stories are characterized by an urgent desire to leave the organizations that cause them to experience personal and professional suffering. Their reasons for leaving the professional career are because they feel few opportunities to develop professional careers in organizations. The problems can be unachieved job challenges, boredom, stagnation, and inhibited creativity. The analysis of the second category reveals the various factors and circumstances that lead to deciding the entrepreneurship as the best choice for career orientation.

The third category refers to value and integrity. It shows that the urge of women to make a career transition is triggered by the fact that organizations are 
less able to facilitate the improvement in the quality of life. They also feel there is a gap between the value system and principles of personal and organization. They believe that it is not possible to change the organization to respect them better. The shift from linear to multidirectional careers can provide many careers, including women leaving their careers to start their businesses. As a result, some senior female managers will opt out of the organization and start hiring themselves if they feel that they receive higher benefits of entrepreneurial career choices.

The last category deals with social capital and human capital. Senior female managers share their experiences in traditional organizations as a learning environment, especially in their early careers. The organizations provide an opportunity for them to gain experience as the capital for developing new businesses. They use this experience to start their business by considering long-term goals and essential skills and getting involved in key networks.

The research has three limitations. First, the career transition research is only conducted on women. Further research can examine the motivation and transition process in men so that different results can be obtained. Second, the research is exploratory, so it needs to be further analyzed by testing the results to be generalized. Third, the research is limited to knowing women's motivation in making career transitions and how women make the transition process. For further research, it is necessary to examine the effects of career transitions before, during, and after choosing a career as an entrepreneur. Besides that, it is also essential to examine how the balance of professional and personal lives of female entrepreneurs. When they have felt the pleasant or unpleasant effects of the transition process, it will affect their satisfaction, performance, and achievement in entrepreneurship.

\section{REFERENCES}

Agarwal, S., \& Lenka, U. (2015). Study on the worklife balance of women entrepreneurs - Review and research agenda. Industrial and Commercial Training, 47(7), 356-362. https://doi.org/10.1108/ ICT-01-2015-0006

Baruch, Y., \& Reis, C. (2016). How global are boundaryless careers and how boundaryless are global careers? Challenges and a theoretical perspective. Thunderbird International Business Review, 58(1), 13-27. https://doi.org/10.1002/tie.21712

Baruch, Y., Szűcs, N., \& Gunz, H. (2015). Career studies in search of theory: The rise and rise of concepts. Career Development International, 20(1), 3-20.

Bott, G., \& Tourish, D. (2016). The critical incident technique reappraised: Using critical incidents to illuminate organizational practices and build theory. Qualitative Research in Organizations and Management, 11(4), 276-300. https://doi.org/10.1108/QROM-01-20161351

Braches, B., \& Elliott, C. (2017). Articulating the entrepreneurship career: A study of German women entrepreneurs. International Small Business Journal, 35(5), 535-557. https://doi. org/10.1177/0266242616651921

Campos, F., Goldstein, M., McGorman, L., Boudet, A. M. M., \& Pimhidzai, O. (2015). Breaking the metal ceiling: Female entrepreneurs who succeed in male-dominated sectors. Policy Research Working Paper, 7503(December), 1-37. https://doi. org/10.1596/1813-9450-7503

Cesaroni, F. M., \& Paoloni, P. (2016). Are family ties an opportunity or an obstacle for women entrepreneurs? Empirical evidence from Italy. Palgrave Communications, 2, 1-7. https://doi.org/10.1057/ palcomms.2016.88

Chuang, Y. F., \& Tai, Y. F. (2016). Research on customer switching behavior in the service industry. Management Research Review, 39(8), 925-939. https://doi.org/10.1108/MRR-01-2015-0022

Cooklin, A. R., Dinh, H., Strazdins, L., Westrupp, E., Leach, L. S., \& Nicholson, J. M. (2016). Change and stability in work-family conflict and mothers' and fathers' mental health: Longitudinal evidence from an Australian cohort. Social Science \& Medicine, 155(April), 24-34. https://doi.org/10.1016/j. socscimed.2016.02.036

Costa, S. F., Caetano, A., \& Santos, S. C. (2016). Entrepreneurship as a career option: Do temporary workers have the competencies, intention and willingness to become entrepreneurs? The Journal of Entrepreneurship, 25(2), 129-154. https://doi. org $/ 10.1177 / 0971355716650363$

Devi, K. R., \& Rani, S. S. (2016). The impact of organizational role stress and work family conflict: Diagnosis sources of difficulty at work place and job satisfaction among women in IT Sector, Chennai, Tamil Nadu. Procedia - Social and Behavioral Sciences, 219, 214-220. https://doi.org/10.1016/j. sbspro.2016.05.008

Devine, T. J. (1994). Changes in wage-and-salary returns to skill and the recent rise in female self-employment. The American Economic Review, 84(2), 108-113.

Du Plessis, C. (2015). Brand storytelling: The case of CocaCola's journey corporate website. Communitas, 20, 84-103.

Falco, P., \& Haywood, L. (2016). Entrepreneurship versus joblessness: Explaining the rise in selfemployment. Journal of Development Economics, 118(January), 245-265. https://doi.org/10.1016/j. jdeveco.2015.07.010

Feldner, S. B., \& Fyke, J. P. (2016). Rhetorically constructing an identity at multiple levels: A case study of Social Entrepreneurship Umbrella Organizations. International Journal of Strategic Communication, 10(2), 101-114. https://doi.org/10.1080/155311 8X.2016.1144188

Foss, N. J., Klein, P. G., \& Bjørnskov, C. (2019). The context of entrepreneurial judgment: Organizations, markets, and institutions. Journal of Management Studies, 56(6), 1197-1213. https://doi.org/10.1111/ joms. 12428

Fuller, B., Liu, Y., Bajaba, S., Marler, L. E., \& Pratt, 
J. (2018). Examining how the personality, selfefficacy, and anticipatory cognitions of potential entrepreneurs shape their entrepreneurial intentions. Personality and Individual Differences, 125, 120125. https://doi.org/10.1016/j.paid.2018.01.005

Gerli, F., Bonesso, S., \& Pizzi, C. (2015). Boundaryless career and career success: The impact of emotional and social competencies. Frontiers in Psychology, 6, 1-17. https://doi.org/10.3389/fpsyg.2015.01304

Ghanbari, R., Sarooghani, B., Darabi, F., Bahri, N., \& Abolfathi, M. (2017). The effect of women's employment on children's quality of life. Journal of Research and Health, 7(3), 803-809.

Goktan, A. B., \& Gupta, V. K. (2015). Sex, gender, and individual entrepreneurial orientation: Evidence from four countries. International Entrepreneurship and Management Journal, 11, 95-112. https://doi. org/10.1007/s11365-013-0278-Z

Goltz, S., Buche, M. W., \& Pathak, S. (2015). Political empowerment, rule of law, and women's entry into entrepreneurship. Journal of Small Business Management, 53(3), 605-626. https://doi. org/10.1111/jsbm.12177

Hall, D. T., Yip, J., \& Doiron, K. (2018). Protean careers at work: Self-direction and values orientation in psychological success. Annual Review of Organizational Psychology and Organizational Behavior, 5, 129-156. https://doi.org/10.1146/ annurev-orgpsych-032117-104631

Hancock, M. G., \& Hums, M. A. (2016). A "leaky pipeline"?: Factors affecting the career development of senior-level female administrators in NCAA Division I Athletic departments. Sport Management Review, 19(2), 198-210. https://doi.org/10.1016/j. smr.2015.04.004

Hasan, F. S. M. A., \& Almubarak, M. M. S. (2016). Factors influencing women entrepreneurs' performance in SMEs. World Journal of Entrepreneurship, Management and Sustainable Development, 12(2), 1-19. https://doi.org/10.1108/wjemsd-09-2015-0037

Henley, A. (2017). The post-crisis growth in the selfemployed: Volunteers or reluctant recruits? Regional Studies, 51(9), 1312-1323. https://doi.org/10.1080/0 0343404.2016 .1184753

Henley, M. M. (2015). Women's success in academic science: Challenges to breaking through the ivory ceiling. Sociology Compass, 9(8), 668-680. https:// doi.org/10.1111/soc4.12291

Hennekam, S., \& Bennett, D. (2016). Involuntary career transition and identity within the artist population. Personnel Review, 45(6), 1114-1131. https://doi. org/10.1108/PR-01-2015-0020

Hoyer, P., \& Steyaert, C. (2015). Narrative identity construction in times of career change: Taking note of unconscious desires. Human Relations, 68(12), 18371863. https://doi.org/10.1177/0018726715570383

Hoyt, C. L., \& Murphy, S. E. (2016). Managing to clear the air: Stereotype threat, women, and leadership. The Leadership Quarterly, 27(3), 387-399. https://doi. org/10.1016/j.leaqua.2015.11.002

Ibarra, H., \& Petriglieri, J. (2016). Impossible selves:
Image strategies and identity threat in professional women's career transitions. In Theorizing women and leadership: New insights and contributions from multiple perspectives (pp. 19-36). Information Age Publishing.

ILO. (2011). Mempromosikan kesetaraan gender dalam dunia kerja "kegiatan pengarusutamaan gender ILO-Jakarta”. Retrieved from https://www.ilo.org/ jakarta/whatwedo/publications/WCMS_161257/ lang--en/index.htm

Jabeen, F., Katsioloudes, M. I., \& Das, S. S. (2015). Is family the key? Exploring the motivation and success factors of female Emirati entrepreneurs. International Journal of Entrepreneurship and Small Business (IJESB), 25(4), 375-394. https://doi. org/10.1504/IJESB.2015.070214

Johannessen, A., Engedal, K., Haugen, P. K., Dourado, M. C. N., \& Thorsen, K. (2018). "To be, or not to be": Experiencing deterioration among people with young-onset dementia living alone. International Journal of Qualitative Studies on Health and WellBeing, 13(1), 1-13. https://doi.org/10.1080/1748263 1.2018.1490620

Justo, R., DeTienne, D. R., \& Sieger, P. (2015). Failure or voluntary exit? Reassessing the female underperformance hypothesis. Journal of Business Venturing, 30(6), 775-792. https://doi.org/10.1016/j. jbusvent.2015.04.004

Lyons, S. T., Schweitzer, L., \& Ng, E. S. W. (2015). How have careers changed? An investigation of changing career patterns across four generations. Journal of Managerial Psychology, 30(1), 8-21. https://doi. org/10.1108/JMP-07-2014-0210

Mensah-Kufuor, A. G., Mensah, I., \& Amenumey, E. K. (2015). Service failures in 3-to 5-star hotels in Accra, Ghana. Journal of Tourism and Hospitality Management, 3(3-4), 73-86. https://doi. org/10.17265/2328-2169/2015.04.003

Miscenko, D., \& Day, D. V. (2016). Identity and identification at work. Organizational Psychology Review, 6(3), 215-247. https://doi. org/10.1177/2041386615584009

Muñoz-Bullon, F., Sanchez-Bueno, M. J., \& Vos-Saz, A. (2015). Startup team contributions and new firm creation: The role of founding team experience. Entrepreneurship \& Regional Development, 27(12), 80-105. https://doi.org/10.1080/08985626.2014. 999719

Ogliastri, E., \& Zúñiga, R. (2016). An introduction to mindfulness and sensemaking by highly reliable organizations in Latin America. Journal of Business Research, 69(10), 4429-4434. https://doi. org/10.1016/j.jbusres.2016.03.008

Page-Jones, S., \& Abbey, G. (2015). Career identity in the veterinary profession. Veterinary Record, 176(17), 433. https://doi.org/10.1136/vr.102784

Paustian-Underdahl, S. C., Halbesleben, J. R. B., Carlson, D. S., \& Kacmar, K. M. (2016). The workfamily interface and promotability: Boundary integration as a double-edged sword. Journal of Management, 42(4), 960-981. https://doi. org/10.1177/0149206313506464 
Pérez-Pérez, C., \& Avilés-Hernández, M. (2016). Explanatory factors of female entrepreneurship and limiting elements. Suma de Negocios, 7(15), 25-31. https://doi.org/10.1016/j.sumneg.2015.12.004

Perreault, W. D., \& Leigh, L. E. (1989). Reliability of nominal data based on qualitative judgments. Journal of Marketing Research, 26(2), 135-148. https://doi.org/10.1177/002224378902600201

Ramanath, R. (2016). Defying NGO-ization?: Lessons in livelihood resilience observed among involuntarily displaced women in Mumbai, India. World Development, 84(August), 1-17. https://doi. org/10.1016/j.worlddev.2016.04.007

Rey-Martí, A., Tur Porcar, A., \& Mas-Tur, A. (2015). Linking female entrepreneurs' motivation to business survival. Journal of Business Research, 68(4), 810814. https://doi.org/10.1016/j.jbusres.2014.11.033

Sharma, S., \& Kaur, R. (2019). Glass ceiling for women and work engagement: The moderating effect of marital status. FIIB Business Review, 8(2), 132-146. https:// doi.org/10.1177/2319714519845770

Sheikh, M. A., Ashiq, A., Mehar, M. R., Hasan, A., \& Khalid, M. (2018). Impact of work and home demands on work life balance: Mediating role of work family conflicts. Pyrex Journal of Business and Finance Management Research, 4(5), 48-57.

Sperandio, J., \& Devdas, L. (2015). Staying close to home: Women's life-choices and the superintendency. Journal of Educational Administration, 53(3), 335353. https://doi.org/10.1108/JEA-08-2013-0088
Svejenova, S., \& Alvarez, J. L. (2017). Changing the C-suite: New chief officer roles as strategic responses to institutional complexity. In New themes in institutional analysis: Topics and issues from European research (pp. 135-161). Edward Elgar Publishing.

Taylor, S. J., Bogdan, R., \& DeVault, M. (2015). Introduction to qualitative research methods: A guidebook and resource. John Wiley \& Sons.

Van der Horst, A. C., Klehe, U. C., \& Van der Heijden, B. I. J. M. (2017). Adapting to a looming career transition: How age and core individual differences interact. Journal of Vocational Behavior, 99(April), 132-145. https://doi.org/10.1016/j.jvb.2016.12.006

Wang, M., \& Wanberg, C. R. (2017). 100 years of applied psychology research on individual careers: From career management to retirement. Journal of Applied Psychology, 102(3), 546-563. https://doi. org/10.1037/ap10000143

Wright, A., Marsh, D., \& Mc Ardle, L. (2019). A darker side of creative entrepreneurship. The Design Journal, 22(sup1), 177-188. https://doi.org/10.1080/1460692 5.2019.1595856

Yi, X., Ribbens, B., Fu, L., \& Cheng, W. (2015). Variation in career and workplace attitudes by generation, gender, and culture differences in career perceptions in the United States and China. Employee Relations, 37(1), 66-82. https://doi.org/10.1108/ER-01-20140005 